\title{
ATTEMPTED SUICIDE IN SOCIAL NETWORKS
}

\author{
BY \\ NORMAN KREITMAN, M.D., D.P.M. \\ Assistant Director, Medical Research Council Unit for Research on the Epidemiology of Psychiatric Illness, University \\ Department of Psychiatry, Morningside Park, Edinburgh 10
}

PETER SMITH, B.Sc.

Medical Research Council Clinical and Population Cytogenetics Research Unit, Western General Hospital, Crewe Road, Edinburgh 4

AND

ENG-SEONG TAN, M.B., B.S., D.P.M.

Currently Professor, Department of Psychological Medicine, University of Malaya, Kuala Lumpur, Malaysia

It is generally agreed that a suicidal attempt commonly represents a bid by the patient to communicate his distress to key figures in his intimate social group (Stengel and Cook, 1958; Farberow and Shneidman, 1961). An implication of this view is that such acts may function as a 'language' employed within such a group in situations where other groups would use less pathological forms of communication. The 'language' component of the act can be recognized only as a social and not as an individual phenomenon, and this leads to the hypothesis that suicidal attempts should be found to be concentrated in socially-linked clusters of individuals. More specifically, it could be predicted that, among the close acquaintances of patients attempting suicide, the number of suicidal attempts would be greater than would be expected from the age, sex, and demographic characteristics of these acquaintances. This study was designed to investigate this hypothesis.

\section{METHOD}

The Regional Poisoning Treatment Centre (R.P.T.C.) at the Royal Infirmary, Edinburgh, receives over $90 \%$ of all hospital-treated cases of attempted suicide in the city (Kessel, McCulloch, Hendry, Leslie, Wallace, and Webster, 1964). Every patient presenting to the hospital with selfpoisoning or self-injury, no matter how seemingly trivial, is admitted for assessment, which includes psychiatric examination. A one-year admission cohort (mid 1962-mid 1963) has already been analysed by Kessel (1965) and McCulloch (1965), and these authors kindly put their data at our disposal for further use. Detailed records have been routinely maintained at the Centre since $1963, \stackrel{\longrightarrow}{\longrightarrow}$ thus providing data for the subsequent years.

Between 16 January and 31 March 1967 an attempt was made by one of us (E.S.T.) to interview $\vec{\oplus}$ all patients admitted to the Centre with a diagnosis of 'attempted suicide', i.e., excluding all clear accidental self-poisonings or accidental self-injuriesOne patient who died in consequence of his act, and who was therefore categorized as a suicide, was also omitted. Patients with multiple admissions during this period (there were seven with two admissions and three with three admissions) were interviewed only once. For each patient identifying data were collected and the psychiatric diagnosis was noted: in addition, each was asked to name certain of his kin and close friends, as detailed below, with their approximate ages and current addresses, and their addresses over the previous four years.

For a random sample of $10 \%$ of the patients information was sought in the same way from another family member at visiting times: in no case were discrepancies elicited between the patient's and the informant's account on any important detail such as the identity of family members, address at any relevant time, or age to within five years. The method of data collection thus seemed reasonably reliable.

The patients will be termed 'probands' and their relatives and friends 'contacts'. Among the contacts, attempted suicides admitted to the R.P.T.C. during the survey period (1 January 1963 to 31 December 1966) were subsequently identified from the hospital registers. 


\section{The Probands}

One important function of the Centre is to provide a rapid screening and psychiatric first-aid service. With approximately 1,000 admissions in 1967 to 20 beds, the turnover is necessarily high, and many patients are discharged within a day of admission. Hence it was not possible to interview all patients, especially as the interviewer could not be constantly present. During the study period 181 persons who had attempted suicide were admitted at least once, and 135 were interviewed: the 46 patients not interviewed included one deaf-mute and one who was too ill, physically, at the close of the study. Table I relates the proband sample to all patients admitted by duration of stay, and shows

TABLE I

CHARACTERISTICS OF PROBAND SAMPLE BY DURATION OF STAY

\begin{tabular}{|c|c|c|c|c|c|c|c|}
\hline \multirow{2}{*}{$\begin{array}{c}\text { Length } \\
\text { of } \\
\text { Stay } \\
\text { (days) }\end{array}$} & \multicolumn{3}{|c|}{$\begin{array}{l}\text { No. of Patients } \\
\text { Admitted }\end{array}$} & \multicolumn{3}{|c|}{$\begin{array}{l}\text { No. of Patients } \\
\text { Interviewed }\end{array}$} & \multirow{2}{*}{$\begin{array}{c}\text { Percentage } \\
\text { of Patients } \\
\text { Interviewed } \\
(\mathbf{M}+\mathbf{F})\end{array}$} \\
\hline & $\mathbf{M}$ & $\mathbf{F}$ & Total & $\mathbf{M}$ & $\mathbf{F}$ & Total & \\
\hline $\begin{array}{l}\overline{0-} \\
\frac{1-}{3-} \\
4+\end{array}$ & $\begin{array}{r}5 \\
19 \\
19 \\
11 \\
19\end{array}$ & $\begin{array}{r}4 \\
34 \\
37 \\
15 \\
18\end{array}$ & $\begin{array}{r}9 \\
53 \\
56 \\
26 \\
37\end{array}$ & $\begin{array}{r}3 \\
10 \\
16 \\
11 \\
17\end{array}$ & $\begin{array}{r}1 \\
20 \\
27 \\
14 \\
16\end{array}$ & $\begin{array}{r}4 \\
30 \\
43 \\
25 \\
33\end{array}$ & $\begin{array}{l}44 \cdot 4 \\
56 \cdot 6 \\
76 \cdot 8 \\
96 \cdot 1 \\
89 \cdot 2\end{array}$ \\
\hline Total & 73 & 108 & 181 & 57 & 78 & 135 & $74 \cdot 6$ \\
\hline
\end{tabular}

that the greatest proportional deficit was among the very rapidly discharged patients, as would be anticipated. Table II compares the probands and total patient group by age and sex. Each age sub-group is represented in approximately equal proportions and there is no apparent sex difference.

TABLE II

CHARACTERISTICS OF PROBAND SAMPLE BY AGE AND SEX

\begin{tabular}{|c|c|c|c|c|c|c|c|c|}
\hline \multirow[t]{2}{*}{ Age } & \multicolumn{3}{|c|}{$\begin{array}{l}\text { No. of } \\
\text { Patients } \\
\text { Admitted }\end{array}$} & \multicolumn{3}{|c|}{$\begin{array}{c}\text { No. of } \\
\text { Patients } \\
\text { Interviewed }\end{array}$} & \multicolumn{2}{|c|}{$\begin{array}{l}\text { Percentage } \\
\text { of Patients } \\
\text { Interviewed }\end{array}$} \\
\hline & $\mathbf{M}$ & $\mathbf{F}$ & Total & $\mathbf{M}$ & $\mathbf{F}$ & Total & $\mathbf{M} \quad \mathbf{F}$ & Total \\
\hline $\begin{array}{l}0-14 \\
15- \\
20- \\
25- \\
35- \\
45- \\
55-\end{array}$ & $\begin{array}{r}0 \\
7 \\
11 \\
18 \\
21 \\
10 \\
6\end{array}$ & $\begin{array}{r}4 \\
19 \\
21 \\
24 \\
16 \\
12 \\
12\end{array}$ & $\begin{array}{l}4 \\
26 \\
32 \\
42 \\
37 \\
22 \\
18\end{array}$ & $\begin{array}{r}0 \\
6 \\
7 \\
14 \\
18 \\
7 \\
5\end{array}$ & $\begin{array}{r}3 \\
16 \\
16 \\
17 \\
9 \\
9 \\
8\end{array}$ & $\begin{array}{r}3 \\
22 \\
23 \\
31 \\
27 \\
16 \\
13\end{array}$ & & $\begin{array}{r}73 \cdot 3 \\
71 \cdot 9 \\
73 \cdot 8 \\
73 \cdot 0 \\
72.7 \\
72.2\end{array}$ \\
\hline All ages & 73 & 108 & 181 & 57 & 78 & 135 & $73.8 \quad 72$ & 274.6 \\
\hline
\end{tabular}

\section{The Contacts}

Each proband was asked to identify and to give the details already specified about his or her father, mother, spouse, children, siblings, and sibling's spouses: he was also asked to name two close friends and to indicate if they were blood-kin, e.g., cousins. Only those contacts were considered who were alive for at least part of the 1963-66 period. There were 1,008 such contacts but, of these, 430 were excluded from the final analysis. An individual was excluded if his (or her) age was unknown (3 cases) or he was aged under 15 years ( 31 cases). A further 396 contacts were resident outside Edinburgh for the whole of the survey period and were therefore also excluded, as attempted suicide rates by geographic area are only available for electoral wards within the city. Thus the population considered to be at risk consisted of 578 individuals. Table III gives the age-sex composition of this population while Table IV shows the composition by type of kinship.

TABLE III

'AT RISK' CONTACT POPULATION BY AGE AND SEX

\begin{tabular}{c|c|c} 
Age & Males & Females \\
\hline $15-$ & 40 & 40 \\
$20-$ & 35 & 27 \\
$25-$ & 68 & 60 \\
$35-$ & 49 & 59 \\
$45-$ & 49 & 43 \\
$55-$ & 37 & 34 \\
$65+$ & 17 & 20 \\
\hline Total & 295 & 283
\end{tabular}

TABLE IV

TYPE OF KINSHIP OF CONTACT POPULATION BY SEX OF PROBAND

\begin{tabular}{|c|c|c|c|}
\hline $\begin{array}{l}\text { Type of } \\
\text { Kinship }\end{array}$ & $\begin{array}{c}\text { No. for } \\
\text { Male } \\
\text { Probands }\end{array}$ & $\begin{array}{l}\text { No. for } \\
\text { Female } \\
\text { Probands }\end{array}$ & Total \\
\hline $\begin{array}{l}\text { Spouse } \\
\text { Father } \\
\text { Mother } \\
\text { Child } \\
\text { Twin } \\
\text { Sibling } \\
\text { Half-sib } \\
\text { Sib's spouse } \\
\text { Friend unrelated } \\
\text { Friend related }\end{array}$ & $\begin{array}{r}25 \\
20 \\
30 \\
9 \\
1 \\
93 \\
0 \\
59 \\
32 \\
0\end{array}$ & $\begin{array}{r}34 \\
27 \\
30 \\
32 \\
0 \\
78 \\
1 \\
54 \\
49 \\
4\end{array}$ & $\begin{array}{r}59 \\
47 \\
60 \\
41 \\
1 \\
171 \\
1 \\
113 \\
81 \\
4\end{array}$ \\
\hline Total & 269 & 309 & 578 \\
\hline
\end{tabular}

Calculation of Expected Numbers. For each of the 578 contacts defined to be in the "population at risk' we attempted to estimate the expectation of being admitted at least once to the R.P.T.C. in the survey period (1963-66) with a diagnosis of attempted suicide. To obtain these expectations we have assumed that each contact is subject to the admission rate which would apply to an 'equivalent' person randomly sampled from the general population of Edinburgh. 
Rates of attempted suicide are known to vary according to the age and sex of the individual and according to the place of residence in the city. The overall admission rate to the Centre has also increased markedly during the period 1963-66 (Aitken, Buglass and Kreitman, 1969). The methods we have used to take account of these facts in the calculation of the expected number of contacts admitted to the Centre are as follows.

Age and Sex. For each of the four years of the period of study a record was available of the number of admissions to the Centre by age and sex. For the purposes of the present survey we wished to know the number of different patients admitted. Data for the mid 1962-63 admission cohort were available for both number of admissions and number of different patients admitted within the 12 months. It was thus possible to determine the ratio of events (admissions) to persons for each age-sex sub-group: this ratio was 203:174 (116.7:100) for all males and $384: 331(116 \cdot 0: 100)$ for all females, and there was no evidence of any systematic divergence from these figures for the age-sex sub-groups (considered by decades) within each sex, and certainly none which approached statistical significance.

Data on admissions and patients later became available for 1967, and the ratios were found to be 123:100 for males and 114:100 for females, again with no important deviation for age sub-groups. We concluded that as an approximation, an eventto-persons ratio of 115:100 would introduce no appreciable error and, further, that since the ratios were so similar at the beginning and end of the survey period (1963-66), the approximation was probably valid for the intermediate years also. The ratio for males may be slightly low, but by using the ratio 115:100 we will overestimate the expected number of patients admitted over the study period and will thus bias against finding an excess of patients in the contact population.

A further adjustment was introduced to exclude patients admitted from outside the city of Edinburgh. The 1962-63 data showed that 25 of the 174 male and 47 of the 331 female patients admitted during that period came from addresses outside the city, and the proportion was about the same for both sexes with no significant deviation among the various age groups. The data for 1967 showed that the proportion of admissions from outside the city had risen from $15 \%$ to approximately $20 \%$, but in our calculations we have used the lower figure, since this would again lead to an overestimate rather than underestimate of the city rates.

Data for 1963, 1964, 1965, and 1966 were available as admissions (not persons) by age and sex. To deter- mine the number of patients admitted from within $\odot$ the city boundary we multiplied the number of $\varnothing$ admissions in each age-sex group first by a factor $\frac{3}{\infty}$ of 0.86 to convert the admissions to patients and $\stackrel{?}{?}$ then by a factor of 0.86 again to obtain an estimate $\overrightarrow{\vec{F}}$ of the number of patients admitted from inside the $\stackrel{\rho}{\rightarrow}$ city. It should be noted that this procedure will further tend to overestimate the number of different $\frac{\bar{\sigma}}{\bar{c}}$ patients admitted as the conversion from admissions $\vec{\nabla}$ to patients is based on data for single years and $\varrho$ some patients will have been admitted to the Centre $\%$ in more than one year of the survey period.

After this adjustment, the resulting estimates of $\stackrel{-}{-}$ the numbers of persons admitted from within the $\vec{\omega}$ city of Edinburgh in each survey year were tabulated $\frac{\text { }}{\mathbb{D}}$ for each age-sex sub-group. They were then averaged $\stackrel{\odot}{\sim}$ to provide the numerator of the average annualit rate. The denominators used were the mid-popula- $-\omega$ tions of the 1961 and 1966 census. Table V shows ${ }_{-}^{-}$ the rates so derived.

TABLE V

AVERAGE ANNUAL ADMISSION RATE (PERSONS) PER 100,000 FOR ATTEMPTED SUICIDE IN EDINBURGH, 1963-66, BY AGE AND SEX

\begin{tabular}{|c|c|c|c|}
\hline Age & Males & Females & \\
\hline $\begin{array}{l}15- \\
20- \\
25- \\
35- \\
45- \\
55- \\
65+\end{array}$ & $\begin{array}{r}191.4 \\
222.9 \\
238 \cdot 0 \\
252 \cdot 3 \\
173 \cdot 5 \\
100 \cdot 1 \\
65.7\end{array}$ & $\begin{array}{r}342.9 \\
432 \cdot 2 \\
399 \cdot 8 \\
282.6 \\
162.6 \\
105 \cdot 7 \\
73 \cdot 2\end{array}$ & $\stackrel{\overline{2}}{\vec{D}}$ \\
\hline
\end{tabular}

In applying these rates to the contact population, the age of each contact (in early 1967) was reduced by two years to give his or her approximate age at the mid-point of the survey period.

Place of Residence. Kessel (1965) has demon- -3 . strated considerable variation in the crude adultio admission rate to the R.P.T.C. for the different 3 electoral wards of Edinburgh. Using his data from 433 patients, classified by age, sex, and place of residence, we have derived 'area factors' by dividingo the observed number of admissions by the number expected, assuming that each of the ward populationso is subject to the same age-sex specific rates as for the city as a whole. The area factors thus calculated are illustrated in the Figure. A similar calculation $\omega$ was done for the 581 patients admitted during 1967 , and the results were found to be very similar, the rank order correlation for the city wards wases $r_{s}=+0.89$. The area factors were evidently ${ }_{D}$ temporally stable.

It has been necessary to assume that the factord 


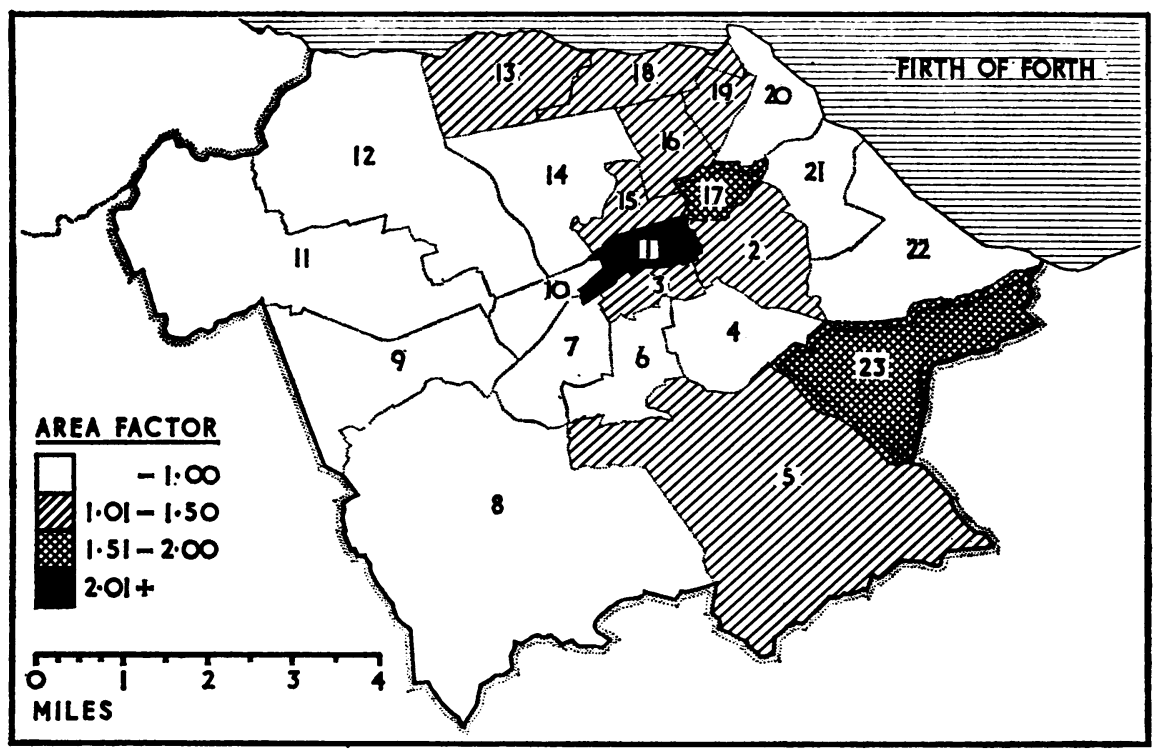

FIGURE. Attempted suicide: Distribution of standardized morbidity ratios:('Area factors'), Edinburgh, $1962-63$.

for any ward was the same in all age-sex groups within the ward. Data were too sparse to enable us to test this assumption critically but no striking discrepancies were found. The estimates of the area factors are subject to considerable variability due to the small number of patients on which the calculations were based. An attempt was made to estimate the size of the error thus introduced. This is discussed later.

Duration of Exposure. For each of the 578 contacts, the time spent in each ward during the survey period was recorded to the nearest month. Individuals residing outside the city for some time were excluded for the time they were absent, and those whose place of residence was unknown for part of the four-year period were assumed (1) to be outside the city and were hence excluded, or (2) to have been resident in the ward with the highest area factor (ward 1). The expected number of admissions to the R.P.T.C. in the contact population was computed under both of these assumptions and very similar results were obtained. The latter has therefore been used throughout, as the small bias so introduced will tend to support the null hypothesis of there being no excess of admissions to the Centre from the contact population, against the alternative hypothesis of there being a positive excess.

The expectation of admission for each contact was determined by multiplying the time spent in each ward by the relevant age-sex specific rate of persons admitted to the R.P.T.C. and the 1962-63 area factor, and then summing when necessary. Having thus established the expected number of admissions for each person in the contact population, it was possible to examine defined groups of contacts and to compare their expected with their actual number of admissions, and to do likewise with the whole contact population.

\section{RESULTS}

Seventeen members of the contact population were admitted to the Centre at least once during the survey period. This is significantly greater than the expected number of 4.23 obtained from the computations detailed above $(P<0.001)$ (see Appendix).

Further analyses were made according to the characteristics of $(a)$ the probands, $(b)$ the contacts, and $(c)$ proband-contact pairs where the contact had made a suicidal attempt.

\section{By Proband Characteristics}

DURATION OF STAY. It will be recalled that our sample of probands under-represented patients rapidly discharged from the ward during the study. We therefore dichotomized the sample at two days (as suggested by Table I) and calculated the number of positive contacts to be expected in each group (E) by the method previously described. It is not desired, however, to test for an excess in each of 
the groups individually but rather to determine whether the magnitude of the excess is proportionately the same in both. Therefore in this and in the following comparisons, the calculated expected numbers in each group have been multiplied by the ratio of the total observed attempted suicides (17) to the total expected $(4 \cdot 23)$. Thus the revised expected numbers $\left(E^{1}\right)$ have been made to total the observed number (17) and the observed and expected distributions between groups have been compared using a $\chi^{2}$ test. In some instances the expected numbers $\left(E^{1}\right)$ were small and a simple simulation experiment was performed to test the validity of the $\chi^{2}$ approximation in these cases. In no case was the simulated distribution found to be markedly different from that of $\chi^{2}$. However, the precise significance level obtained should be interpreted with some caution because of the previously discussed sampling error associated with the expected numbers of attempted suicides.

For the data on duration of stay the observed and expected distributions were found to be not significantly different (Table VI).

TABLE VI

PROBAND CHARACTERISTICS: DURATION OF STAY AND DISTRIBUTION OF POSITIVE CONTACTS

\begin{tabular}{|c|c|c|c|c|}
\hline \multirow{3}{*}{$\begin{array}{l}\text { Duration of } \\
\text { Patient's } \\
\text { Stay (days) }\end{array}$} & \multirow{3}{*}{$\begin{array}{l}\text { No. of } \\
\text { Contacts } \\
\text { at Risk }\end{array}$} & \multicolumn{3}{|c|}{ Positive Contacts } \\
\hline & & $\begin{array}{c}\text { No. } \\
\text { Observed }\end{array}$ & $\begin{array}{c}\text { No. } \\
\text { Expected }\end{array}$ & $\begin{array}{l}\text { Proportion } \\
\text { Expected }\end{array}$ \\
\hline & & (O) & (B) & $\left(\mathbf{E}^{1}\right)$ \\
\hline $\begin{array}{l}<2 \\
2+\end{array}$ & $\begin{array}{l}141 \\
437\end{array}$ & $\begin{array}{r}2 \\
15\end{array}$ & $\begin{array}{l}0.98 \\
3 \cdot 25\end{array}$ & $\begin{array}{r}3.94 \\
13.06\end{array}$ \\
\hline Total & 578 & 17 & $4 \cdot 23$ & $17 \cdot 00$ \\
\hline
\end{tabular}

Age AND Sex. Age and sex were considered in an analogous manner, and the results are given in Table VII. There appears to be no difference between the sexes in the frequency with which patients have a positive contact, but patients below 35 years of age have a relative excess, and older patients a relative lack of such contacts $(P<0.02)$. The data also suggest that this age effect is principally found among women, though the numbers on which this calculation is based are small.

Mode of Suicidal Atrempt. The commonest method of 'attempted suicide' in Edinburgh is self-poisoning with drugs (Aitken et al., 1969).
TABLE VII

PROBAND CHARACTERISTICS: AGE AND SEX, AND DISTRIBUTION OF POSITIVE CONTACTS

\begin{tabular}{|c|c|c|c|c|}
\hline \multirow{3}{*}{$\begin{array}{l}\text { Proband } \\
\text { Charac- } \\
\text { teristic }\end{array}$} & \multirow{3}{*}{$\begin{array}{l}\text { No. of } \\
\text { Contacts } \\
\text { at Risk }\end{array}$} & \multicolumn{3}{|c|}{ Positive Contacts } \\
\hline & & $\begin{array}{c}\text { No. } \\
\text { Observed }\end{array}$ & $\begin{array}{l}\text { No. } \\
\text { Expected }\end{array}$ & $\begin{array}{l}\text { Proportion } \\
\text { Expected }\end{array}$ \\
\hline & & (O) & (E) & $\left(E^{1}\right)$ \\
\hline $\begin{array}{l}\text { Sex } \\
\text { Male } \\
\text { Female }\end{array}$ & $\begin{array}{l}269 \\
309\end{array}$ & $\begin{array}{l}8 \\
9\end{array}$ & $\begin{array}{l}2 \cdot 11 \\
2 \cdot 12\end{array}$ & $\begin{array}{l}8 \cdot 48 \\
8 \cdot 52\end{array}$ \\
\hline Total & $\begin{array}{l}578 \\
\chi^{2}=0.054 \\
\text { df }=1 \\
P<0.80\end{array}$ & 17 & $4 \cdot 23$ & $17 \cdot 00$ \\
\hline $\begin{array}{c}\text { Age (years) } \\
-34 \\
35+\end{array}$ & $\begin{array}{l}299 \\
279\end{array}$ & $\begin{array}{r}14 \\
3\end{array}$ & $\begin{array}{l}2.27 \\
1.96\end{array}$ & $\begin{array}{l}8 \cdot 93 \\
8 \cdot 07\end{array}$ \\
\hline Total & $\begin{array}{l}\quad 578 \\
\chi^{2}=6.063 \\
\text { df }=1 \\
P<0.02\end{array}$ & 17 & $4 \cdot 23$ & $17 \cdot 00$ \\
\hline $\begin{array}{c}\text { Age and sex } \\
\mathbf{M}-\mathbf{3 4} \\
\mathbf{3 5}+ \\
\mathbf{F}-\mathbf{3 4} \\
\mathbf{3 5}+\end{array}$ & $\begin{array}{l}135 \\
134 \\
164 \\
145\end{array}$ & $\begin{array}{l}5 \\
3 \\
9 \\
0\end{array}$ & $\begin{array}{l}1 \cdot 17 \\
0.94 \\
1 \cdot 10 \\
1.02\end{array}$ & $\begin{array}{l}4 \cdot 70 \\
3 \cdot 78 \\
4 \cdot 42 \\
4 \cdot 10\end{array}$ \\
\hline Total & 578 & 17 & $4 \cdot 23$ & $17 \cdot 00$ \\
\hline
\end{tabular}

Distinguishing such patients from all those usieg. other modes, as in Table VIII, shows that all theo positive contacts were among the entourage of the self-poisoning probands. The mode of attempt is thus significantly associated with the distribution of: positive contacts $(P<0.05)$.

TABLE VIII

PROBAND CHARACTERISTICS: MODE OF ATTEMPT AND DISTRIBUTION OF POSITIVE CONTACTS

\begin{tabular}{|c|c|c|c|c|}
\hline \multirow{3}{*}{$\begin{array}{c}\text { Mode } \\
\text { of } \\
\text { Attempt }\end{array}$} & \multirow{3}{*}{$\begin{array}{l}\text { No. of } \\
\text { Contacts } \\
\text { at Risk }\end{array}$} & \multicolumn{3}{|c|}{ Positive Contacts } \\
\hline & & $\begin{array}{l}\text { No. } \\
\text { Observed }\end{array}$ & $\begin{array}{c}\text { No. } \\
\text { Expected }\end{array}$ & $\begin{array}{c}\text { Proportion } \\
\text { Expected }\end{array}$ \\
\hline & & (0) & (E) & $\left(E^{1}\right)$ \\
\hline $\begin{array}{l}\text { Drugs } \\
\text { Other }\end{array}$ & $\begin{array}{l}476 \\
102\end{array}$ & $\begin{array}{r}17 \\
0\end{array}$ & $\begin{array}{l}3.34 \\
0.89\end{array}$ & $\begin{array}{r}13.42 \\
3.58\end{array}$ \\
\hline Total & 578 & 17 & $4 \cdot 23$ & 17.00 \\
\hline
\end{tabular}

Other variables examined for an effect on the distribution of positive contacts included social class, marital status, previous admissions to the R.P.T.C., the diagnosis of the psychiatric illness? present on admission, personality type, birth order, and size of sibship. None yielded statisticallyo significant findings. 


\section{By Contact Characteristics}

It seemed possible that certain classes of the contact population might be especially likely to have an excess of positive contacts among them. Age and sex appeared to be unimportant in this connexion, nor were we able to show that any one of seven types of kinship with the proband was specially at risk. The number of contacts in each kinship category was sometimes small, but we wished to consider the important possibility that the excess of positive contacts in the population at risk might reflect genetic linkage with the probands. The kinship categories were therefore summarized into those with blood relationships (parents, siblings, children, and related friends) and those without blood ties (spouses, spouses of sibs, and unrelated friends). It can be seen in Table IX that although there is some excess of positive contacts in the blood kin group, the excess is not statistically significant.

TABLE IX

CONTACT CHARACTERISTICS: TYPE OF KINSHIP AND DISTRIBUTION OF POSITIVE CONTACTS

\begin{tabular}{|c|c|c|c|c|}
\hline \multirow{3}{*}{$\begin{array}{c}\text { Type } \\
\text { of } \\
\text { Kinship }\end{array}$} & \multirow{3}{*}{$\begin{array}{l}\text { No. of } \\
\text { Contacts } \\
\text { at risk }\end{array}$} & \multicolumn{3}{|c|}{ Positive Contacts } \\
\hline & & $\begin{array}{c}\text { No. } \\
\text { Observed }\end{array}$ & $\begin{array}{c}\text { No. } \\
\text { Expected }\end{array}$ & $\begin{array}{l}\text { Proportion } \\
\text { Expected }\end{array}$ \\
\hline & & (O) & (B) & $\left(E^{1}\right)$ \\
\hline $\begin{array}{l}\text { Blood kin } \\
\text { Other }\end{array}$ & $\begin{array}{l}324 \\
254\end{array}$ & 12 & $\begin{array}{l}2 \cdot 21 \\
2 \cdot 02\end{array}$ & $\begin{array}{l}8 \cdot 88 \\
8 \cdot 12\end{array}$ \\
\hline Total & 578 & 17 & $4 \cdot 23$ & $17 \cdot 00$ \\
\hline
\end{tabular}

Patient-contact Relationship

Finally we examined the 17 pairs of patients and their positive contacts.

TIME INTERVAL. The time interval between the admissions of the contacts and the probands can be seen in Table X. Since three contacts had multiple

TABLE X INTERVAL BETWEEN ADMISSION OF POSITIVE CONTACTS AND PATIENTS IN 1967

\begin{tabular}{c|c|c|c}
\hline $\begin{array}{c}\text { Year of } \\
\text { Contact's } \\
\text { Admission }\end{array}$ & $\begin{array}{c}\text { Interval } \\
\text { between } \\
\text { Admissions } \\
\text { (years*) }\end{array}$ & \multicolumn{2}{|c|}{$\begin{array}{c}\text { No. of Positive Contacts admitted } \\
\text { at Stated Interval }\end{array}$} \\
\hline 1963 & $\begin{array}{c}\text { First Admission } \\
\text { of Contact }\end{array}$ & $\begin{array}{c}\text { Last Admission } \\
\text { of Contact }\end{array}$ \\
\hline 1964 & 4 & 4 & 2 \\
1965 & 2 & 2 & 2 \\
1966 & 1 & 4 & 3 \\
\hline
\end{tabular}

-Represents difference in calendar years of admissions, not actual dates. admissions within the survey period the data for the contacts' first and latest admissions are shown separately. Though the numbers are very small it can be seen that most of the contacts' admissions (by either classification) tend to fall in the later part of the survey period.

Age, Sex, ANd Kinship. The small number of pairs and the diversity of kinships make our data little more than anecdotal in this context. Table XI illustrates the matching between probands and positive contacts by age, sex, and the kinship of the contact to the proband. No female patient over 35

TABLE XI

AGE, SEX, AND RELATIONSHIP OF POSITIVE CONTACT TO PROBANDS

\begin{tabular}{|c|c|c|c|c|}
\hline \multirow{3}{*}{$\begin{array}{l}\text { Positive } \\
\text { Contacts }\end{array}$} & \multicolumn{4}{|c|}{ Probands } \\
\hline & \multicolumn{2}{|c|}{ Male } & \multicolumn{2}{|l|}{ Female } \\
\hline & -34 & $35+$ & -34 & $35+$ \\
\hline $\begin{array}{l}\text { Male } \\
-34\end{array}$ & $\begin{array}{l}\text { Brother } \\
\text { Brother } \\
\text { Brother }\end{array}$ & Brother & $\begin{array}{l}\text { Brother } \\
\text { Brother } \\
\text { Boy-friend }\end{array}$ & \\
\hline \multicolumn{5}{|l|}{$35+$} \\
\hline $\begin{array}{c}\text { Female } \\
-34\end{array}$ & $\begin{array}{l}\text { Girl-friend } \\
\text { Sister-in-law }\end{array}$ & $\begin{array}{l}\text { Wife } \\
\text { Step-daughter }\end{array}$ & $\begin{array}{l}\text { Daughter } \\
\text { Sister } \\
\text { Sister-in-law }\end{array}$ & \\
\hline $35+$ & & & $\begin{array}{l}\text { Mother } \\
\text { Friend } \\
\text { Friend }\end{array}$ & \\
\hline
\end{tabular}

had a positive contact, and no positive contacts were men over 35 . Within the series there was no statistically significant concordance for age or sex. The average ages of the probands on admission and the positive contacts at the mid-point of the survey period were very similar, with respective means and standard errors of $25.5 \pm 1.9$ and 24.9 $\pm 3 \cdot 2$. Nearly all the positive male contacts were brothers.

Diagnosis. There was no significant association within the series of pairs on illness diagnosis in four broad diagnostic categories. The personality diagnosis of one positive contact was uncertain; among the remaining 16 pairs, 11 were alike in being classified as normal or abnormal, evidence for the latter being addiction to drugs, alcoholism or markedly psychopathic behaviour (Table XII). This rather high proportion is of interest but is not great enough to permit rejection of the null hypothesis. 
TABLE XII

PROBAND-CONTACT PAIRS: ASSOCIATION ON PERSONALITY DIAGNOSIS

\begin{tabular}{l|c|c|c}
\hline \multicolumn{1}{c|}{ Contact } & \multicolumn{2}{|c}{ Proband } & Total \\
\cline { 2 - 3 } & $\begin{array}{c}\text { Normal } \\
\text { Personality }\end{array}$ & $\begin{array}{c}\text { Abnormal } \\
\text { Personality }\end{array}$ & Tor \\
\hline Normal personality & 5 & 1 & 6 \\
Abnormal personality & 4 & 6 & 10 \\
\hline Total & 9 & 7 & 16 \\
\hline
\end{tabular}

$P=0.241$ (Fisher's Exact Probability Test)

\section{Discussion}

The central methodological problem in this study has been the estimation of the number of individuals in the population of contacts who would be expected to have at least one episode of hospital treatment for 'attempted suicide' during the survey period. Demonstration of an excess of observed to expected positive contacts in such a population, with expectation derived solely from data on age, sex, and duration of risk, would be inadequate for our purpose, since such a result would be interpreted to mean little more than that the families and close friends of the probands shared the social stresses which are so widespread among patients attempting suicide. To make allowance for commonality of experience, we have used area factors to supplement demographic data. These factors reflect not only defined variables likely to influence rates of attempted suicide but also further and as yet unidentified variables which at present can only be demonstrated geographically (Buglass, Dugard, and Kreitman, 1968). How far the patients are typical of their areas has been explored elsewhere (Philip, and McCulloch, 1966; McCulloch and Philip, 1967; Buglass et al., 1968). Here it must be pointed out that characteristics which distinguish the various city wards may also distinguish between the patient (and his family) and the rest of the population in his own ward. Thus a level of social disorganization which is typical of a particular ward may under-represent the amount of disorganization to be found among the attempted suicides (and their families) within that ward. In so far as this is so, we will have under-estimated the expected number of positive cases in the contact population. Our results must therefore be interpreted with caution.

The most important single finding was the fourfold excess of observed to expected numbers of positive contacts. This alone does not, of course, establish the 'language' theory of suicidal behaviour but is certainly compatible with it. Significantly more younger than older probands had a positive contact, and there was a suggestion that the age effect might be particularly important for women Both these findings are in accord with what is known of other forms of shared psychopathology $\overrightarrow{\vec{F}^{2}}$ especially epidemic hysteria. It was also found thaf positive contacts were significantly more numerous for probands using self-poisoning rather than self $\overline{\bar{n}}$. injury. It is noteworthy that the rapid rise in admis- $-\bar{\phi}$ sion rates for attempted suicide in Edinburgh over the last five years (Aitken et al., 1969) has been entirely due to increasing self-poisoning: it is thus $\overrightarrow{0}$ possible that the rise is at least partly due to case- to-case spread.

Among the contact population, age and sex did not influence the proportional excess of positive? contacts. It is important to note that the slightin excess of positive cases among those contactsi linked genetically with the probands was notstatistically significant. Any familial transmissiono of predisposition to suicidal behaviour is therefore응 more likely to be culturally than genetically deter- mined.

It would seem that if we are correct in interpreting our findings as compatible with the communication $\overrightarrow{0}$ hypothesis, then we have succeeded in characterizipges the 'recipients' in the communication process, namely the probands, more closely than the 'trafs mitters' or positive contacts. It may well be thät only certain classes of individuals behave in ano imitative and symmetrical manner in the context $\frac{\circ}{\circ}$ of the self-aggression of others. But clearly a further $\stackrel{\varrho}{\rightarrow}$ understanding of the process would require close $\overrightarrow{\vec{B}}$ study of pairs of individuals. In this respect the present study has yielded too few examples for adequate analysis, and can only serve as a pointer to further studies based on larger samples.

\section{SUMMARY}

It is proposed that the concept of 'attempted suicide' as a form of communication leads to the hypothesis that suicidal attempts should occur in socially-linked groups of individuals with a frequency $\frac{7}{0}$ greater than would be expected from a sample of the general population matched for those demogra- $N$ phic factors known to influence rates of attempted $N$ suicide.

Between 1 January and 31 March 1967, 181 persons diagnosed as attempted suicides were admitted to the Regional Poisons Treatment Centre, Royal Infirmary, Edinburgh, of whom 135 were interviewed to ascertain, inter alia, details of their close associates ('contacts') including name, age, 0 sex, and residence between January 1962 and December 1966. The data were checked from another 
family member in $10 \%$ of the patients and were found to be of acceptable reliability. Contacts who for at least part of the survey period were alive, aged over 15, and resident in Edinburgh totalled 578: these constituted the 'population at risk'.

For each individual contact the expectation of being admitted to the R.P.T.C. at least once during the survey period was calculated, using previously determined rates for age, sex, and duration of residence in each of the city wards; for the latter, 'area factors' calculated as standardized morbidity ratios were used, their sampling errors being estimated by a computer simulation technique (Appendix).

The actual number of attempted suicides was ascertained by checking each contact's name in the Centre's registers.

For the whole group of patients, 17 positive contacts were identified, which was significantly greater than the expected number of 4.23 (P $<0.001$ ). There was evidence that an excess of positive contacts was characteristic of female patients $(P<0.05)$, of those below 35 years of age $(P<0.02)$, and of those using drugs in their suicidal attempt $(P<0.05)$; other variables were without significant effect.

Although there was some excess of positive contacts among the blood kin of patients as compared with other family members and friends, the excess was slight and not statistically significant.

There was tentative evidence that the positive contacts tended to have made their suicidal attempt towards the end of the survey period rather than uniformly over the four years at risk.

The results were reviewed and, with certain reservations, it was concluded that the findings were compatible with the hypothesis advanced.

Acknowledgements are due to Dr. H. Matthew, Regional Poisoning Treatment Centre, Royal Infirmary, Edinburgh and his colleagues for permission to conduct the study and to publish the results. Thanks are made to Dr. I. Oswald, Consultant Psychiatrist to the R.P.T.C., for his collaboration and advice, to Miss Patricia Duncan for computational assistance and are also due to Professor G. M. Carstairs for his helpful criticisms.

\section{REFERENCES}

Aitken, C., Buglass, Dorothy, and Kretrman, N. (1969). The changing pattern of attempted suicide in Edinburgh 1962-1967. Brit. J. prev. soc. Med., 23,111.

Buglass, Dorothy, Dugard, Pat, and Kreitman, N. (1968). Subcultural factors in attempted suicide. Unpublished.

Farberow, N., and Shneidman, E. (1961). The Cry for Help. McGraw-Hill, New York.
KeSSEL, N. (1965). Self-poisoning. Brit. med. J., 2, 1265, 1336.

-, McCulloch, W., Hendry, Joyce, Leslie, Dorothy, Wallace, I., and Webster, R. (1964). Hospital management of attempted suicide in Edinburgh. Scot. med. J., 9, 333.

MCCULlOCH, J. W. (1965). The social consequences of acts of deliberate self-poisoning or self-injury. M.Sc. Dissertation (unpublished). Edinburgh.

$\longrightarrow$, and PHILIP, A. E. (1967). Social variables in attempted suicide. Acta psychiat, scand., 43, 341.

Philip, A. E., and McCulloch, J. W. (1966). Use of social indices in psychiatric epidemiology. Brit. $J$. prev. soc. Med., 20, 122.

STENGel, E., and CoOK, N. G. (1958). Attempted Suicide. (Maudsley Monographs, No. 4). Chapman and Hall, London.

\section{APPENDIX}

In performing the test of significance we have assumed that, under the null hypothesis, the observed number of patients admitted is a sample drawn from a Poisson distribution with mean equal to the expected number of patient admissions. However, it is clearly not the case that the estimate of the expected number is free from sampling error. The estimation of the age and sex specific rates is computed from data collected over four years and is based on large numbers of admissions, but, as has been previously noted, some error will be introduced in the estimation of the area factors. In order to examine what effect this may have made on the estimation of the expected number of admissions we have performed a simulation experiment.

It was assumed that the area factors $\left(f_{i}\right)$ for 1962 were in fact the true factors. We then randomly distributed the 433 cases amongst the 23 wardsthe probability of a case being placed in ward $i$ being made proportional to the area factor $\left(f_{i}\right)$ multiplied by the expected number in the ward $\left(e_{i}\right)$-i.e., in proportion to the number of the original sample falling in each ward $\left(f_{\mathrm{i}} \times e_{\mathrm{i}}=n_{\mathrm{i}}\right)$. The experiment thus involved simulating a multinomial distribution with 23 classes, the probability associated with the $i$ class being $n_{\mathrm{i}} \Sigma n_{\mathrm{i}}$. Having redistributed the 433 cases, new area factors were obtained by dividing the 'simulated' number in each ward by the expected number $\left(e_{\mathrm{i}}\right)$. These area factors were applied to the contact population to give an estimate of the expected number of admissions.

In all, 500 such samples were drawn and the expected number of admissions was calculated from each. The mean was 4.221 and the standard deviation was $0 \cdot 144,95 \%$ of the simulated values falling between 3.94 and 4.50 .

It would therefore seem that the assumption made in performing the test of significance, although not strictly correct, is going to introduce very little bias in the significance level obtained. 